\title{
FAKTOR YANG MEMPENGARUHI NIAT MAKAN SAYUR DAN BUAH PADA MAHASISWA ASRAMA UNIVERSITAS AIRLANGGA
}

\author{
FACTOR THAT AFFECT INTENTION TO EAT VEGETABLES AND FRUIT IN \\ STUDENT DORMITORY OF AIRLANGGA UNIVERSITY
}

\author{
Dwi Pandrya Dhaneswara \\ Departemen Promosi Kesehatan dan Ilmu Perilaku \\ Fakultas Kesehatan Masyarakat, Universitas Airlangga Surabaya \\ Email : pandryadhaneswara@gmail.com
}

\begin{abstract}
Fruit and vegetable consumption in Indonesia is low. Adolescents are one of the most vulnerable age group about consumption of vegetables and fruit. Eating habits during adolescence will give an impact on health in the future. College students are the age group of transition from late adolescence into early adulthood. This research will show the behavior of eating vegetables and fruit on a college student in a dorm. This research was a cross sectional study with quantitative approach. Instruments in this study were questionnaire with a sample of 79 college student. Sampling used simple random sampling method. The variables in the study were attitude toward behavior, subjective norms, behavioral control, and intention of eating vegetables and fruits. Variables that affected intention of eating vegetables and fruits was attitudes toward behavior $(p=0.001)$. Attitude toward behavior with $(B$ $=16.785)$ contributed on the intention to eat vegetables and fruit. The conclusion of this study, attitudes toward behavior affected the intention to eat vegetables and fruit, while subjective norms, and behavior control were not affected.
\end{abstract}

Keyword: Intention, eating, fruit and vegetable

\begin{abstract}
Abstrak : Konsumsi sayur dan buah di Indonesia masih rendah. Remaja merupakan kelompok usia yang paling rentan dalam hal konsumsi sayur dan buah. Kebiasaan makan semasa remaja akan memberikan dampak pada kesehatan dalam masa depannya. Mahasiswa merupakan kelompok usia transisi dari masa remaja akhir menjadi dewasa awal. Penelitian ini dilakukan untuk melihat niat makan sayur dan buah pada mahasiswa asrama. Penelitian ini menggunakan rancang bangun cross sectional dengan pendekatan kuantitatif. Instrumen dalam penelitian ini adalah kuisioner dengan sampel berjumlah 79 orang. Pengambilan sampel menggunakan metode simple random sampling. Variabel dalam penelitian ini adalah sikap, norma subyektif, kontrol perilaku dan, niat makan sayur dan buah. Variabel yang memiliki pengaruh terhadap niat makan sayur dan buah adalah sikap $(\mathrm{p}=0,001)$. Variabel sikap memberikan kontribusi terhadap niat makan sayur dan buah dalam nilai Exp (B) sebesar 18,333. Kesimpulan dari penelitian ini adalah sikap berpengaruh terhadap niat makan sayur dan buah, sedangkan norma subyektif, dan kontrol perilaku tidak berpengaruh.
\end{abstract}

Kata kunci: Niat, makan, buah dan sayur

\section{PENDAHULUAN}

Makan dengan menu seimbang (appropriate diet) merupakan salah satu cerminan perilaku hidup sehat (Notoatmodjo, 2007). Menu seimbang artinya kualitas dan kuantitas makanan cukup untuk memenuhi kebutuhan tubuh. Makanan yang dimakan setidaknya mencukupi tiga fungsi yaitu sebagai zat tenaga (karbohidrat), zat pembangun (protein), dan zat pengatur (vitamin dan mineral). Makanan yang dikonsumsi seharihari harus beraneka ragam agar diperoleh zat gizi yang seimbang untuk mencukupi kebutuhan tubuh (Almatsier, 2004).

Kurangnya asupan sayur dan buah menjadi salah satu masalah yang berkaitan dengan perilaku makan. Hal ini bisa menyebabkan tubuh kekurangan nutrisi seperti serat, mineral, vitamin dan tidak seimbangnya asam basa tubuh jika kurang dalam konsumsi sayur dan buah. Selain itu dapat menimbulkan berbagai macam penyakit (Sekarindah, 2008). Laporan World Health Organization (WHO) pada tahun 2003 menyebutkan sebanyak $11 \%$ penyakit 
stroke dan $31 \%$ penyakit jantung di seluruh dunia disebabkan oleh kurangnya konsumsi sayur dan buah (WHO, 2003).

Konsumsi sayur dan buah sesuai anjuran bisa mencegah terjadinya berbagai macam penyakit degeneratif seperti diabetes, hipertensi, obesitas, penyakit jantung koroner (PJK) dan kanker (Almatsier, 2006). Beberapa penelitian menunjukkan bahwa konsumsi sayur dan buah yang cukup dapat menurunkan resiko terjadinya beberapa penyakit kronik. Hasil penelitian $\mathrm{He}$ et al (2007), menyebutkan peningkatan konsumsi buah yang sebelumnya kurang dari 3 porsi menjadi lebih dari 5 porsi sehari berkaitan dengan penurunan $17 \%$ risiko terjadinya PJK. Studi meta-analysis Dauchet et al (2005), risiko terjadinya stroke menurun sebesar $11 \%$ untuk setiap tambahan porsi buah per hari.

Menurut WHO (2003), rekomendasi untuk makan sayur dan buah adalah sebanyak 3-5 porsi sehari atau sebanyak 400 gram perhari. Selain itu dalam piramida penunjuk makanan merekomendasikan untuk makan sayur sebanyak 3-5 kali dalam sehari dan buah sebanyak 2-4 kali (Rahmawati, 2000). Konsumsi sayur dan buah di Indonesia masih rendah. Hal ini bisa dilihat pada rerata konsumsi sayur dan olahannya sebesar 57,1 gram/orang/hari. Rerata konsumsi buah dan olahannya juga terlihat masih rendah yaitu 33,5 gram/orang/ hari (Survei Diet Total, 2014).

Remaja menjadi kelompok usia yang sangat rentan jika mereka kurang dalam makan sayur dan buah. Hal ini dikarenakan masa remaja adalah periode yang penting dalam pertumbuhan dan perkembangan manusia. Pada masa remaja merupakan saat yang tepat untuk pertumbuhan dan perkembangannya dalam menanamkan kebiasaaan makan yang sehat. Jika pada masa remaja pola makannya sudah tidak sehat maka bisa berdampak pada kesehatan di masa depannya (Wulansari, 2009).

Mahasiswa merupakan kelompok usia transisi dari masa remaja akhir menjadi dewasa awal yang lebih mandiri dalam menentukan makanan apa yang akan dikonsumsi. Masa remaja akhir dapat dilihat dengan pertumbuhan yang melambat. Pada tahap ini, remaja akan lebih memikirkan rencana yang akan datang dan meningkatkan pergaulan di lingkungan serta hidup lebih mandiri (Poltekkes Depkes Jakarta I, 2010).

Berdasarkan pengambilan data awal pada mahasiswa di asrama putra dan putri Universitas Airlangga dengan jumlah 20 responden dari 10 mahasiswa dan 10 mahasiswi didapatkan bahwa sebanyak 50\% tidak mengkonsumsi sayur dan buah setiap hari. Mahasiwa yang tinggal di asrama putra dan putri sebanyak $60 \%$ rata-rata hanya mengkonsumsi buah 1 porsi/hari. Konsumsi sayur didapatkan sebesar $35 \%$ untuk 1 porsi/ hari dan $65 \%$ untuk 2 porsi/hari.

Mahasiswa sebagai generasi penerus bangsa dan bagian dari masyarakat Indonesia diharapkan memiliki perilaku hidup dan pola makan yang sehat. Oleh karena itu perlu adanya faktor-faktor yang mendukung, yang mampu mengarahkan seorang mahasiswa untuk berperilaku menjaga kesehatannya, seperti konsumsi sayur dan buah sesuai anjuran. Faktor itu bisa dari diri sendiri, keluarga, teman, maupun lingkungannya.

Niat merupakan faktor yang paling berpengaruh untuk memunculkan perilaku. Niat juga diasumsikan sebagai determinan langsung dari perilaku dan mengarahkan perilaku yang berada dalam kendali seseorang. Semakin kuat niat seseorang untuk menampilkan suatu perilaku, semakin besar kemungkinan perilaku tersebut akan dilakukan. Niat makan sayur dan buah pada mahasiswa diharapkan mampu memunculkan perilaku untuk makan sayur dan buah.

Niat dari suatu perilaku hanya dapat muncul jika seseorang mampu memutuskan keinginannya untuk melakukan atau tidak melakukan perilaku. Ajzen (2005), menjelaskan dalam Theory of Planned Behavior bahwa faktor yang dapat mempengaruhi niat adalah sikap, norma subyektif, dan kontrol perilaku. Semakin positif sikap, norma subyektif, dan kontrol perilaku terhadap perilaku untuk makan sayur dan buah dalam memprediksi niat, diharapakan niat dapat menggambarkan perilakunya untuk makan sayur dan buah.

Tujuan umum dari penelitian adalah menganalisis faktor yang mempengaruhi niat makan sayur dan buah pada mahasiswa 
asrama Universitas Airlangga berdasarkan Theory of Planned Behavior. Tujuan khususnya yang pertama adalah untuk melihat kararkterisitik mahasiswa asrama Universitas Airlangga. Tujuan yang kedua untuk mengidentifikasi sikap, norma subyektif, kontrol perilaku dan niat untuk makan sayur dan buah pada mahasiswa asrama. Ketiga adalah untuk menganalisis pengaruh sikap, norma subyektif, dan kontrol perilaku terhadap niat makan sayur dan buah.

\section{METODE}

Penelitian ini merupakan penilitian Observasional analitik dengan menggunakan pendekatan kuantitatif. Berdasarkan waktu pengambilan data, penelitian ini bersifat cross sectional.

Populasi mahasiswa yang tinggal di asrama Universitas Airlangga adalah 376 mahasiswa. Asrama putra berjumlah 150 orang dan untuk asrama putri berjumlah 226 orang. Sampel dalam penelitian ini adalah mahasiswa asrama yang dihitung menggunakan rumus simple random sampling sebanyak 79 mahasiswa sebagai responden .

Lokasi penelitian ini berada di Asrama Mahasiswa Putra dan Putri Universitas Airlangga. Penelitian ini dilakukan antara bulan Maret-April 2016. Teknik pengumpulan data primer dimulai dengan peneliti menjelaskan pada responden tentang penjelasan tujuan dan pelaksanaan penelitian. Setelah responden memahami akan dilakukan pengisian dan penandatanganan lembar persetujuan (informed consent). Pengisian kuesioner dilakukan dalam waktu sekitar 20 menit yang dilaksanakan di asrama di luar jam kuliah.

Variabel bebas atau independen dalam penelitian ini adalah sikap, norma subyektif dan kontrol perilaku dalam makan sayur dan buah pada mahasiswa asrama Universitas Airlangga. Variabel terikat atau dependen dalam penelitian ini adalah niat untuk makan buah dan sayur pada mahasiswa asrama Universitas Airlangga.

Pengolahan data menggunakan teknik skoring yang kemudian dianalisis dengan tujuan untuk melihat pengaruh sikap, norma subyektif, dan kontrol perilaku terhadap niat untuk makan buah dan sayur dengan uji regresi logistik. Sebelumnya, skor pada tiap variabel akan dikategorikan dalam rentang tingkatan untuk mengetahui gambaran pada subyek penelitian. Sikap, norma subyektif dan kontrol perilaku memiliki kategori kurang baik, baik, sangat baik. Niat dikategorikan kedalam kuat dan dan lemah.

Pengukuran variabel sikap, norma subyektif, dan kontrol perilaku menggunakan 6 skala. Sikap dihitung menggunakan rumus:

\section{$A B i \infty \Sigma$ bi ei}
$\mathrm{AB}_{\mathrm{i}} \quad$ : total nilai attitude untuk setiap responden
$b_{i} \quad: \quad$ skor behavioral beliefs untuk setiap pertanyaan
$\mathrm{e}_{\mathrm{i}} \quad$ : skor outcome evaluations untuk setiap pertanyaan

Norma subyektif dihitung menggunakan rumus:

\section{$S N i \infty \sum n i m i$}
$\mathrm{SN}_{\mathrm{i}}$ : total nilai subjective norm setiap responden
$\mathrm{n}_{\mathrm{i}} \quad$ : skor normative beliefs untuk setiap pertanyaan
$\mathrm{m}_{\mathrm{i}} \quad$ : skor motivation to comply untuk setiap pertanyaan

Sedangkan untuk nilai kontrol perilaku yang dirasakan dihitung dengan rumus:

\section{$P B C i \propto \Sigma c i p i$}

\begin{tabular}{|c|c|}
\hline $\mathrm{PBC}_{\mathrm{i}}$ & $\begin{array}{l}\text { : total nilai perceived } \\
\text { behavioral control untuk } \\
\text { setiap responden }\end{array}$ \\
\hline & $\begin{array}{l}\text { skor control belief untuk } \\
\text { setiap pertanyaan }\end{array}$ \\
\hline & $\begin{array}{l}\text { skor perceived power untuk } \\
\text { setiap pertanyaan }\end{array}$ \\
\hline
\end{tabular}


Berdasarkan rentang nilai total untuk sikap (AB) secara langsung dibagi menjadi tiga berdasarkan sifat pengaruh nilai $\mathrm{AB}$ tersebut terhadap perilaku, yaitu: $5 \leq \mathrm{AB}$ $<60=$ kurang baik, $60 \leq \mathrm{AB}<120=$ baik, $120 \leq \mathrm{AB} \leq 180=$ sangat baik. Rentang nilai total untuk norma subyektif (SN secara langsung dibagi menjadi tiga berdasarkan sifat pengaruh nilai $\mathrm{SN}$ tersebut terhadap perilaku, yaitu: $6 \leq \mathrm{SN}<099$ o $70=$ kurang baik, $70 \leq \mathrm{SN}<140=$ baik $140 \leq \mathrm{SN} \leq$ $216=$ sangat baik. Rentang nilai total untuk kontrol perilaku yang dirasakan (PBC) secara langsung dibagi menjadi tiga berdasarkan sifat pengaruh nilai $\mathrm{PBC}$ tersebut terhadap perilaku, yaitu:5 $\leq \mathrm{PBC}<$ $60=$ kurang baik, $60 \leq \mathrm{PBC}<120=$ baik, $120 \leq \mathrm{PBC} \leq 180=$ sangat baik.

Data tersebut selanjutnya ditabulasi dan dianalisis secara deskriptif dengan menggunakan uji satistik Regresi Logistik Berganda untuk mengetahui pengaruh antara variabel bebas terhadap variabel terikat. Data Hasil observasi yang diperoleh dikumpulkan kemudian diolah dan disajikan dalam bentuk tabel yang kemudian diolah dan dianalisis secara deskriptif.

\section{HASIL PENELITIAN}

Pada penelitian ini dapat dilihat karakterisitik penghuni asrama mahasiswa sebagai responden berdasarkan jenis kelamin, umur, fakultas, dan uang saku. Karakteristik responden dilihat sebagai latar belakang responden dalam niat makan sayur dan buah.

Pada penelitian ini mayoritas responden berjenis kelamin perempuan dengan usia antara 18-20 tahun. Penghuni asrama adalah mahasiswa dari berbagai fakultas di Universitas Airlangga. Mayoritas penghuni asrama adalah mahasiswa Fakultas Sains dan Teknologi (FST), Kedokteran Hewan (FKH), dan Kesehatan Masyarakat (FKM). Hal ini dikarenakan lokasi asrama yang juga masuk kedalam kawasan kampus $\mathrm{C}$ Universitas Airlangga.

Berdasarkan tabel 1 menunjukkan mayoritas mahasiswa mempunyai uang saku dalam kategori sedang yaitu sebesar Rp 500.000-Rp 1.000.000. Hal ini menggambarkan bahwa mayoritas
Tabel 1. Karakteristik Responden berdasarkan Jenis Kelamin, Umur, Fakultas dan Uang Saku pada Mahasiswa Asrama Universitas Airlangga tahun 2016

\begin{tabular}{lcc}
\hline Jenis Kelamin & N & $\mathbf{\%}$ \\
\hline Laki-Laki & 32 & $40,5 \%$ \\
Perempuan & 47 & $59,5 \%$ \\
Total & 79 & $100 \%$ \\
\hline Umur Responden & $\mathbf{N}$ & $\mathbf{\%}$ \\
\hline 17 tahun & 2 & $2,5 \%$ \\
18 tahun & 17 & $21,5 \%$ \\
19 tahun & 36 & $45,6 \%$ \\
20 tahun & 20 & $25,3 \%$ \\
20 tahun keatas & 4 & $5,1 \%$ \\
Total & 79 & $100 \%$ \\
\hline Fakultas & $\mathbf{N}$ & $\mathbf{\%}$ \\
\hline FST & 31 & $39,2 \%$ \\
FKM & 18 & $22,8 \%$ \\
FKH & 12 & $15,2 \%$ \\
FKP & 3 & $3,8 \%$ \\
FPK & 7 & $8,9 \%$ \\
FH & 1 & $1,3 \%$ \\
FISIP & 2 & $2,5 \%$ \\
FV & 1 & $1,3 \%$ \\
FEB & 2 & $2,5 \%$ \\
FIB & 2 & $2,5 \%$ \\
Total & 79 & $100 \%$ \\
\hline Uang Saku & $\mathbf{N}$ & $\mathbf{\%}$ \\
\hline Tinggi & 7 & $8,9 \%$ \\
Sedang & 57 & $72,2 \%$ \\
Rendah & 15 & $19,0 \%$ \\
Total & 79 & $100 \%$ \\
\hline & & \\
\hline & &
\end{tabular}

mahasiswa memiliki uang saku yang cukup untuk membeli sayur dan buah. Uang saku responden juga menujukkan bahwa mayoritas responden tergolong dalam kelompok ekonomi menengah keatas.

Berdasarkan tabel 1 mayoritas responden memiliki Sikap terhadap Perilaku yang sangat baik tentang makan sayur dan buah (62 dari 79). Sikap dapat dibentuk oleh pengetahuan yang baik terhadap suatu perilaku tertentu. Mahasiswa dengan tingkat pendidikan tinggi memungkinkan untuk memiliki sikap yang baik untuk makan sayur dan buah.

Berdasarkan tabel 2 Mayoritas mahasiswa memiliki norma subyektif yang sangat baik untuk makan sayur dan buah yaitu sebesar 67,1\%. Mahasiswa tergolong pada usia remaja menuju dewasa, sehingga telah memiliki kedewasaan sikap 
Tabel 2. Distribusi Responden berdasarkan Sikap, Norma Subyektif, kontrol perilaku dan niat pada Mahasiswa Asrama Universitas Airlangga tahun 2016

\begin{tabular}{lcc}
\hline Sikap & $\mathbf{N}$ & $\mathbf{\%}$ \\
\hline Sangat Baik & 62 & $78,5 \%$ \\
Baik & 17 & $21,5 \%$ \\
Kurang Baik & 0 & $0 \%$ \\
Total & $\mathbf{7 9}$ & $\mathbf{1 0 0 \%}$ \\
\hline Norma Subyektif & $\mathbf{N}$ & $\mathbf{\%}$ \\
\hline Sangat Baik & 53 & $67,1 \%$ \\
Baik & 26 & $32,9 \%$ \\
Kurang Baik & 0 & $0 \%$ \\
Total & $\mathbf{7 9}$ & $\mathbf{1 0 0 \%}$ \\
\hline Kontrol Perilaku & $\mathbf{N}$ & $\mathbf{\%}$ \\
\hline Sangat Baik & 32 & $40,5 \%$ \\
Baik & 39 & $49,4 \%$ \\
Kurang Baik & 8 & $10,1 \%$ \\
Total & $\mathbf{7 9}$ & $\mathbf{1 0 0} \%$ \\
\hline Niat & $\mathbf{N}$ & $\mathbf{\%}$ \\
\hline Kuat & 46 & $58,2 \%$ \\
lemah & 33 & $41,8 \%$ \\
Total & $\mathbf{7 9}$ & $\mathbf{1 0 0 \%}$ \\
\hline
\end{tabular}

untuk mengikuti lingkungannya. Dengan lingkungan yang mendukung untuk makan sayur dan buah dapat memunculkan norma subyektif yang mendukung juga untuk makan sayur dan buah.

Berdasarkan tabel 2 Terdapat 49,4\% responden yang memiliki kontrol perilaku yang baik tentang makan sayur dan buah (39 dari 79). Tetapi beberapa responden masih memiliki kontrol perilaku yang kurang baik tentang makan sayur dan buah.

Kontrol perilaku bisa dibentuk berdasarkan tingkat kemudahan atau kesulitan untuk memunculkan perilaku. Mayoritas responden telah memiliki kemudahan untuk untuk makan sayur dan buah, tetapi masih ditemukan juga beberapa responden yang mungkin kesulitan untuk makan sayur dan buah.

Berdasarkan tabel 2 mayoritas responden memiliki Niat yang kuat untuk makan sayur dan buah. Dapat dikatakan bahwa mahasiswa asrama memiliki keinginan yang kuat untuk memenuhi kebutuhan nutrisinya agar tetap terjaga kesehatannya dengan makan sayur dan buah.
Tabel 3. Tabulasi Silang antara Sikap dengan Niat Makan Sayur dan Buah di Asrama Mahasiswa Universitas Airlangga Tahun 2016

\begin{tabular}{lcccccc}
\hline \multirow{2}{*}{ AB } & \multicolumn{4}{c}{ Niat } & \multirow{2}{*}{ Total } \\
\cline { 2 - 5 } & \multicolumn{2}{c}{ Lemah } & \multicolumn{2}{c}{ Kuat } & & \\
\cline { 2 - 6 } & $\mathbf{n}$ & $\mathbf{\%}$ & $\mathbf{n}$ & $\mathbf{\%}$ & $\mathbf{N}$ & $\mathbf{\%}$ \\
\hline KB & 0 & 0 & 0 & 0 & 0 & 0 \\
B & 15 & 88,2 & 2 & 11,8 & 17 & 100 \\
SB & 18 & 29 & 44 & 71 & 62 & 100 \\
Total & 33 & 41,8 & 46 & 58,2 & 79 & 100 \\
\hline \multicolumn{6}{c}{ Sig $=0,000$} \\
\hline
\end{tabular}

Ket. $\mathrm{AB}=$ Sikap, $\mathrm{KB}=$ Kurang Baik, $\mathrm{B}=$ Baik, $\mathrm{SB}=$ Sangat Baik.

Berdasarkan tabel 3 mayoritas responden dengan sikap $(\mathrm{AB})$ yang sangat baik (SB) memiliki niat yang kuat untuk makan sayur dan buah. Beberapa mahasiswa asrama Universitas Airlangga dengan sikap yang sangat baik ada yang memiliki niat yang lemah untuk makan sayur dan buah.

Hal ini munjukkan bahwa responden dengan sikap yang baik tidak selalu mempunyai niat yang kuat untuk makan sayur dan buah. Berdasarkan hasil uji regresi logistik sederhana antara sikap terhadap perilaku dan niat makan sayur dan buah memiliki nilai signifikansi sebesar 0,000 . Dapat dikatakan bahwa ada pengaruh antara sikap terhadap perilaku dan niat makan sayur dan buah.

Tabel 4. Tabulasi Silang antara Norma Subyektif dengan Niat Makan Sayur dan Buah di Asrama Mahasiswa Universitas Airlangga Tahun 2016

\begin{tabular}{lcccccc}
\hline & \multicolumn{3}{c}{ Niat } & \multirow{2}{*}{ Total } \\
\cline { 2 - 6 } SN & \multicolumn{2}{c}{ Lemah } & \multicolumn{1}{c}{ Kuat } & & \\
\cline { 2 - 6 } & $\mathbf{n}$ & $\mathbf{\%}$ & $\mathbf{n}$ & $\mathbf{\%}$ & $\mathbf{n}$ & $\mathbf{\%}$ \\
\hline KB & 0 & 0 & 0 & 0 & 0 & 0 \\
B & 15 & 57,7 & 11 & 42,3 & 26 & 100 \\
SB & 18 & 34 & 35 & 66 & 53 & 100 \\
Total & 33 & 41,8 & 46 & 58,2 & 79 & 100 \\
\hline \multicolumn{6}{c}{ Sig $=0,047$} \\
\hline
\end{tabular}

Ket. SN=Norma Subyektif, KB=Kurang Baik, $\mathrm{B}=$ Baik, $\mathrm{SB}=$ Sangat Baik. 
Berdasarkan tabel 4 mayoritas responden dengan norma subyektif (SN) yang sangat baik (SB) memiliki niat yang kuat untuk makan sayur dan buah. Meskipun begitu ada beberapa responden dengan norma subyektif yang sangat baik tetapi masih memiliki niat yang lemah untuk makan sayur dan buah.

Berdasarkan hasil uji regresi logistik sederhana antara norma subyektif dan niat makan sayur dan buah diketahui memiliki nilai signifikansi sebesar 0,047 . Dapat dikatakan bahwa ada pengaruh yang signifikan antara norma subyektif pada responden dengan niat makan sayur dan buah.

Berdasarkan tabel 5 mayoritas responden dengan kontrol perilaku (PBC) yang sangat baik juga memiliki niat yang kuat untuk makan sayur dan buah. Tetapi dapat dilihat juga bahwa ada beberapa responden dengan kontrol perilaku sangat baik (SB) namun memiliki niat yang lemah untuk makan sayur dan buah. Sebaliknya beberapa responden dengan kontrol perilaku yang kurang baik semuanya memiliki niat yang lemah untuk makan sayur dan buah. Hal ini menunjukkan tidak selalu responden dengan kontrol perilaku yang baik memiliki niat yang kuat.

Berdasarkan hasil uji regresi logistik sederhana antara kontrol perilaku dan niat makan sayur dan buah menunjukkan nilai signifikansi sebesar 0,039. Dapat dikatakan bahwa ada pengaruh yang signifikan antara persepsi kontrol perilaku yang dimiliki

Tabel 5. Tabulasi Silang antara Kontrol Perilaku dengan Niat Makan Sayur dan Buah di Asrama Mahasiswa Universitas Airlangga Tahun 2016

\begin{tabular}{lcccccc}
\hline \multirow{2}{*}{ PBC } & \multicolumn{4}{c}{ Niat } & \multirow{2}{*}{ Total } \\
\cline { 2 - 6 } & \multicolumn{2}{c}{ Lemah } & \multicolumn{2}{c}{ Kuat } & \multicolumn{1}{c}{} \\
\cline { 2 - 6 } & $\mathbf{n}$ & $\mathbf{\%}$ & $\mathbf{n}$ & $\mathbf{\%}$ & $\mathbf{N}$ & $\mathbf{\%}$ \\
\hline KB & 8 & 100 & 0 & 0 & 8 & 100 \\
\hline B & 19 & 48,7 & 20 & 51,3 & 39 & 100 \\
SB & 6 & 18,8 & 26 & 81,3 & 32 & 100 \\
Total & 33 & 41,8 & 46 & 58,2 & 79 & 100 \\
\hline \multicolumn{4}{c}{ Sig $=0,039$} \\
\hline
\end{tabular}

Ket. $\mathrm{PBC}=$ Kontrol Perilaku, $\mathrm{KB}=$ Kurang Baik, $\mathrm{B}=$ Baik, $\mathrm{SB}=$ Sangat Baik.
Tabel 6. Hasil Uji Regresi Pengaruh Sikap, Norma Subyektif, dan Kontrol Perilaku yang Dirasakan terhadap Niat Makan Sayur dan Buah di Asrama Mahasiswa Universitas Airlangga Tahun 2016

\begin{tabular}{lccc}
\hline $\begin{array}{c}\text { Variabel } \\
\text { Bebas }\end{array}$ & $\begin{array}{c}\text { Variabel } \\
\text { Terikat }\end{array}$ & Sig & Pengaruh \\
\hline $\mathrm{AB}$ & & 0,001 & + \\
$\mathrm{SN}$ & Niat & 0,866 & - \\
$\mathrm{PBC}$ & & 0,105 & - \\
\hline \multicolumn{2}{c}{ Variabel Bebas } & Exp (B) \\
\hline \multicolumn{2}{r}{ Sikap (AB) } & 18,333 \\
\hline
\end{tabular}

Ket. $A B=$ Sikap, SN=Norma Subyektif, $\mathrm{PBC}=$ Kontrol Perilaku

responden dalam makan sayur dan buah dengan niat makan sayur dan buah.

Analisis multivariat menggunakan analisis statistik regresi logistik berganda. Analisis dilakukan untuk melihat pengaruh sikap, norma subyektif, dan kontrol perilaku secara bersama-sama terhadap niat.

Hasil uji regresi logistik berganda yang terlihat pada tabel 6 , dari ketiga variabel bebas, yaitu: sikap, norma subyektif, dan kontrol perilaku, hanya variabel jenis sikap yang menunjukkan adanya pengaruh signifikan terhadap niat untuk makan sayur dan buah. Dapat disimpulkan bahwa hanya variabel sikap yang dapat digunakan untuk pendugaan niat makan sayur dan buah.

Variabel sikap kemudian dijadikan pendugaan dalam membandingkan besarnya kemungkinan mahasiswa asrama yang memiliki niat kuat untuk makan sayur dan buah dibanding dengan yang lemah. Besarnya pembandingan tersebut dilihat berdasarkan nilai Exp (B).

Dapat dilihat bahwa semakin baik sikap maka niat untuk makan sayur dan buah akan meningkat 18,333 kalinya. Dapat disimpulkan juga juga semakin baik sikap menimbulkan niat yang semakin kuat untuk makan sayur dan buah. Dari hasil ini menunjukkan bahwa sikap merupakan faktor utama yang menentukan niat mahasiswa untuk makan sayur dan buah. Sikap sendiri dapat dibentuk melalui keyakinan individu tentang manfaat makan sayur dan buah. 


\section{PEMBAHASAN}

Menurut Arisman (2004) remaja lakilaki memerlukan lebih banyak energi dibandingkan dengan perempuan karena perbedaan komposisi tubuh dan kecepatan pertumbuhan. Perempuan mempunyai selera makan yang berubah-ubah dan cenderung lebih memperhatikan jumlah makanan yang mereka konsumsi. Perempuan akan makan sayur dan buah lebih banyak daripada lakilaki meskipun dalam porsi yang lebih sedikit (Baker dan Wardle, 2003).

Banyak penelitian yang menunjukkan adanya kecenderungan perbedaan konsumsi pangan laki-laki dan perempuan. Menurut Dewi (1997), laki-laki cenderung tidak suka makanan yang ringan atau tidak membuat kenyang. Hal ini juga dapat memunculkan perbedaan konsumsi sayur dan buah pada laki-laki maupun perempuan (Wulansari, 2009).

Mayoritas penghuni asrama Universitas Airlangga adalah perempuan. Responden perempuan kemungkinan akan memiliki niat makan sayur dan buah yang lebih besar dibandingkan dengan laki-laki. Responden perempuan berada pada asrama putri dan responden laki-laki pada asrama putra. Asrama putra dan putri memiliki jarak yang tidak berjauhan. Keduanya berada kedalam kawasan Kampus C Universitas Airlangga.

Uang saku berhubungan dengan pendapatan keluarga. Pendapatan merupakan salah satu faktor dalam memilih makanan. Pemilihan makanan yang semakin baik karena pendapatan yang semakin tinggi juga. Menurut Suhardjo (2003), meningkatnya pendapatan seseorang dapat menimbulkan perubahan dalam konsumsi makanannya. Termasuk disini adalah konsumsi sayur dan buah bagi mahasiswa. Pada penelitian Zenk (2005), menunjukkan sesorang dengan penghasilan dan status ekonomi semakin meningkat akan lebih banyak dalam konsumsi sayur dan buah.

Mahasiswa yang tinggal di asrama mayoritas memiliki uang saku kategori sedang dengan kisaran antara Rp 500.0001.000.000. Hal ini menggambarkan bahwa mayoritas mahasiswa memiliki uang saku yang cukup untuk makan sayur dan buah. Uang saku dapat menggambarkan status ekonomi keluarga mahasiswa asrama.
Semakin besar pendapatan kelurga maka semakin besar juga pengeluaran untuk konsumsi sayur dan buah.

Soekirman (2000), mengatakan bahwa tingginya pendapat seseorang cenderung diikuti dengan tingginya jumlah makanan yang akan dikonsumsi. Penelitian Mac Farlane (2007), menunjukkan bahwa masyarakat dengan status ekonomi yang tinggi akan selalu tersedia sayur dan buah dirumah sehingga konsumsi sayur dan buahnya akan lebih tinggi dibandingkan dengan keluarga ekonomi rendah.

Keluarga dengan pendapatan yang rendah akan sulit memenuhi kebutuhan makannya sesuai dengan yang diperlukan tubuh. Uang yang terbatas tidak akan memberikan banyak pilihan terhadap makanan yang akan dikonsumsi. Hartoyo (1997) dalam Bahria (2009), mengatakan bahwa buah secara ekonomi merupakan barang normal dengan elastisitas pengeluaran yang positif. Hal ini berarti dengan meningkatnya pendapatan seseorang maka konsumsi sayur dan buah juga akan semakin meningkat.

Hasil penelitian menunjukkan karakteristik mahasiswa yang dijadikan sebagai responden berdasarkan kategori umur mayoritas penghuni asrama berkisar antara 18-20 tahun dengan jumlah terbanyak pada umur 19. Hal ini menunjukkan bahwa penghuni asrama mahasiswa masih tergolong dalam kelompok usia remaja akhir.

Usia 18-21 tahun merupakan kriteria remaja akhir sebelum memasuki usia dewasa. Ciri-ciri remaja akhir atau late adolescence dapat dilihat dengan pertumbuhan yang mulai lambat tetapi tetap berlangsung. Perkembangan emosi, konsentrasi dan cara berpikir sudah mulai stabil pada remaja akhir. Terjadinya peningkatan kemampuan dalam penyelesaian masalah. Pada tahap ini, remaja sudah mulai memiliki rencana yang akan darang, dan bagaimana meningkatkan pertemanan serta hidup lebih mandiri (Poltekkes Depkes Jakarta I, 2010).

Perilaku makan pada masa remaja akan menetap hingga dewasa nanti (Brown, 2005). Kebiasaan makan yang dilakukan semasa remaja akan memberikan dampak pada kesehatan dalam masa depannya yaitu 
ketika dewasa dan usia lanjut (Arisman, 2009). Preferensi makanan remaja masa kini cenderung pada makanan yang tinggi gula, tinggi lemak, rendah vitamin dan mineral. Hal ini akan berdampak buruk untuk kesehatan di masa yang akan datang (Brown, 2005).

Salah satu kelompok usia yang paling rentan jika kurang konsumsi sayur dan buah adalah remaja. Masa remaja merupakan periode yang penting pada pertumbuhan dan kematangan manusia. Pada periode ini merupakan saat yang tepat untuk membangun tubuh dan menanamkan kebiasaaan pola makan yang sehat. Jika sejak remaja pola makan seseorang sudah tidak sehat, maka hal tersebut akan berdampak pada kesehatan yang akan datang (Wulansari, 2009).

Pada masa remaja seseorang rentan mengalami masalah gizi. Remaja merupakan masa peralihan dari masa anak-anak ke masa dewasa yang ditandai dengan perubahan fisik, fisiologis dan psikososial. Kelompok ini berada pada fase pertumbuhan yang pesat (Growth Spurt) sehingga dibutuhkan gizi yang relatif besar jumlahnya (Aritonang, I.dkk, 2009).

Berdasarkan Theory of Planned Behavior yang dikemukakan oleh Ajzen (2005), sikap ditentukan oleh keyakinan terhadap konsekuensi yang timbul dari suatu perilaku yang ditampilkan. Ajzen menyatakan bahwa keyakinan dapat diperoleh dengan melihat bagaimana perilaku tesebut jika dimunculkan maupun tidak dimunculkan akan memberikan manfaat maupun kerugian yang akan didapatkan sebagai konsekuensi. Evaluasi dari berbagai informasi yang masuk kedalam individu tentang perilaku tertentu dapat memperkuat keyakinan sesorang terhadap perilaku tersebut mauapun sebaliknya.

Seseorang yang percaya bahwa berperilaku tertentu akan memberikan pada hasil yang baik bagi dirinya, maka seseorang akan memiliki sikap yang baik juga. Sedangkan apabila seseorang percaya bahwa berperilaku tertentu akan memberikan hasil yang tidak baik baginya, maka sseorang akan bersikap tidak baik juga (Ajzen, 1985).
Sikap terhadap perilaku dibentuk oleh keyakinan yang diperoleh dari konsekuensi dalam menampilkan suatu perilaku yang bisa disebut dengan behavioral beliefs (Ajzen, 2005). Hal ini berkaitan dengan penilaian seseorang secara subyektif terdahap sekitarnya dan kemampuan untuk memahami lingkungan tersebut. Menurut Azwar (2011), faktor yang mempengaruhi sikap adalah pengalaman pribadi, kebudayaan, orang lain yang dianggap penting, media massa, serta faktor emosi dalam diri individu. Penelitian Badrialaily (2004), menunjukkan adanya hubungan antara pengetahuan dan sikap gizi mahasiswa terhadap serat.

Pada penelitian ini sikap diukur melalui manfaat makan sayur dan buah bagi responden. Keyakinan ini yang nantinya yang nantinya akan dijadikan dugaan terhadap niat untuk makan sayur dan buah. Hasil penelitian menunjukkan bahwa sebanyak 78,5\% responden memiliki sikap yang sangat baik terkait perilaku makan sayur dan buah. Sikap yang sangat baik ini menunjukkan bahwa mahasiswa asrama Universitas Airlangga memiliki sikap yang mendukung terbentuknya niat makan sayur dan buah.

Norma subyektif adalah persepsi individu terhadap pandangan orang sekitar dalam menampilkan maupun tidak menampilkan perilaku tertentu dan kesediaan untuk mematuhi tuntutan dari tokoh yang penting menurut dirinya (Ajzen, 2005). Norma subjektif berkaitan dengan perasaan dan dugaan seseorang tentang harapan terhadap orang-orang yang berada di lingkungan sekitarnya dalam menampilkan perilaku tertentu. Subjective norm ditentukan oleh referent dan motivation to comply atau keinginan untuk mengikuti.

Sama dengan sikap terhadap perilaku, maka norma subjektif juga ditentukan oleh keyakinan. Perbedaannya adalah sikap merupakan keyakinan terhadap perilaku yang diperoleh dari diri sendiri, sedangkan norma subyektif merupakan keyakinan yang diperoleh dari orang lain. Norma subyektif adalah keyakinan yang didapat dari berbagai pandangan orang di sekitarnya yang dianggap penting oleh orang itu dalam menampilkan perilaku. 
Norma subyektif tidak hanya dipengaruhi oleh referent atau orang penting disekitarnya, tetapi juga dipengaruhi oleh keinginan untuk mengikuti tutuntan orang di sekitarnya. Menurut Ajzen (2005), jika seseorang yakin bahwa kebanyakan referent mendukung untuk berperilaku tertentu, dan dia memiliki motivasi untuk mengikutinya, maka sesorang akan mendapatkan tekanan sosial untuk melakukan perilaku itu. Sebaliknya, jika seseorang memiliki keyakinan bahwa kebanyakan referent tidak mendukung dalam menampilkan perilaku tertentu, dan motivasi untuk memunculkan perilaku itu tidak ada, maka akan menimbulkan norma subyektif dalam seseorang untuk tidak memunculkan perilaku tertentu. Pada penelitian ini referent adalah orang tua, teman dan pandangan masyarakat terhadap makan sayur dan buah.

Berdasarkan hasil penelitian mayoritas mahasiswa asrama Universitas Airlangga memiliki norma subyektif yang sangat baik $(67,1 \%)$. Banyaknya responden yang memiliki norma subyektif yang baik tentunya tidak hanya dipengaruhi oleh tuntutan tokoh penting namun berkaitan juga dengan keinginan responden untuk memenuhi tuntutan itu.

Perceived behavioral control atau bisa disebut juga dengan kontrol perilaku adalah persepsi seseorang tentang kemudahan atau kesulitan serta ada tidaknya sumber daya dalam menampilkan suatu perilaku tertentu. Kontrol perilaku yang dirasakan, menurut Theory of Planned Behavior (Ajzen, 2005) adalah keyakinan seseorang mengenai kemudahan maupun kesulitan atau yang bisa menghalangi dalam menampilkan suatu perilaku tertentu. Keyakinan ini dapat didasari oleh pengalaman yang sudah dialami dirinya, tetapi juga bisa didapatkan dari pengalaman orang lain. Selain itu juga dipengaruhi oleh faktor lain yang meningkatkan atau menurunkan persepsi mengenai kesulitan untuk menampilkan suatu perilaku tertentu.

Ajzen (2005), mengungkapkan bahwa kontrol perilaku berbeda dengan locus of control atau pusat kendali yang pernah disampaikan oleh Rotter's. Pada locus of control keyakinan seseorang bisa relatif stabil dalam berbagai macam situasi. Sedangkan persepsi kontrol perilaku dapat berubah-ubah sesuai situasi maupun perilaku yang akan ditampilkan

Perilaku seseorang tidak hanya berada dalam kendalinya, melainkan dapat dipengaruhi dari adanya sumberdaya, dan kemampuan untuk menampilkan perilaku itu (Ajzen, 2002). Persepsi kontol perilaku menggambarkan tentang keyakinan seseorang dalam kemudahan untuk menampilkan perilaku. Jika seseorang merasa bahwa dirinya kekurangan sumberdaya maupun mendapatkan kesulitan dan tidak mempunyai kesempatan dalam menampilkan suatu perilaku makan niat untuk menampilkan perilaku itu juga akan semakin rendah

Faktor pengukuran dalam kemudahan maupun kesulitan untuk menampilkan perilaku dalam penelitian ini adalah kemampuan mahasiswa untuk membeli, kemudahan akses, dan akibat kedepannya dalam memunculkan perilaku. Dari hasil penelitian, mayoritas responden dapat dikatakan memiliki kontrol perilaku yang baik. Hal ini menunjukkan bahwa mayoritas responden merasa mudah untuk makan sayur dan buah.

Niat atau intensi merupakan komponen dalam diri individu yang mengacu pada keinginan untuk melakukan tingkah laku tertentu (Ajzen, 1985). Niat adalah kesungguhan seseorang untuk melakukan perbuatan atau memunculkan suatu perilaku tertentu. Niat menghubungkan antara pertimbangan sesorang yang sudah dipengaruhi berbagai faktor dan diyakini maupun diinginkan untuk menampilkan suatu perilaku tertentu.

Menurut Theory of Planned Behavior, seseorang dapat bertindak sesuai dengan niatnya jika orang itu memiliki kontrol dalam menampilkan perilaku tersebut (Ajzen, 2002). Teori ini tidak hanya melihat perilaku manusia secara rasional tetapi juga berasal dari keyakinan seseorang bahwa perilaku dipengaruhi oleh kontrol atau kesedaran seseorang dalam menampilkannya. Suatu perilaku tidak hanya bergantung pada niat seseorang tetapi juga bisa berdasarkan faktor lain yang tidak dibawah kontol atau kesadaran orang itu seperti kemudahan 
akses, ketersediaan sumberdaya, dan adanya kesempatan untuk menampilkan perilaku (Ajzen, 2005).

Pada penelitian ini niat diukur berdasarkan keinginan responden untuk makan sayur dan buah disaat ini dan yang akan datang. Mayoritas responden telah memiliki niat yang kuat untuk makan sayur dan buah. Hal ini menunjukkan mayoritas mahasiswa asrama memiliki niat yang positif untuk memunculkan perilaku makan sayur dan buah.

Hasil penelitian menunjukkan hanya variabel sikap yang berpengaruh secara signifikan terhadap niat makan sayur dan buah. Analisis dilakukan untuk melihat pengaruh sikap, norma subyektif dan kontol perilaku terhadap niat makan sayur dan buah pada mahasiswa asrama Universitas Airlangga. Sedangkan variabel norma subyektif dan kontrol perilaku tidak memberikan pengaruh terhadap niat makan sayur dan buah. Berdasarkan sikap responden menunjukkan bahwa semakin baik sikap makan niat untuk makan sayur dan buah akan semakin kuat. Dapat disimpulkan bahwa semakin baik sikap maka niat untuk makan sayur dan buah akan semakin besar. Hal ini telah sesuai dalam Theory of Planned Behavior yang dikemukaka oleh Ajzen (2005), yang menyebutkan bawa sikap terhadap perilaku merupakan salah satu faktor pembentuk niat.

Sikap terhadap perilaku didapatkan dari penjumlahan hasil kali antara kekuatan belief (kepercayaan) terhadap perilaku dan evaluasi terhadap perilaku tersebut. Sikap positif ditandai dengan mayoritas responden menyadari akan manfaat makan sayur dan buah sesuai kebutuhan dan akan menguntungkan bagi tubuh mereka. Hal ini berarti bahwa penghuni asrama telah memiliki kepercayaan atau keyakinan dan evaluasi yang positif untuk makan sayur dan buah sehingga memunculkan niat yang positif juga untuk makan sayur dan buah. Dibuktikan dengan hasil penelitian yang menunjukkan adanya pengaruh antara sikap niat responden untuk makan sayur dan buah.

Pada Theory of Planned Behavior disebutkan bahwa dari ketiga variabel yang paling berpengaruh adalah variabel yang paling dianggap penting (Ajzen, 2005). Hal ini menunjukkan bahwa sikap memberikan pengaruh paling besar terhadap niat makan sayur dan buah. Sesuai dengan penelitian Rusdin (2011), terkait pemilihan penolong persalinan, bahwa variabel sikap terhadap perilaku merupakan variabel yang paling berpengaruh terhadap niat.

Sikap terhadap makan sayur dan buah menunjukkan pengaruhnya yang paling besar dalam niat untuk makan sayur dan buah. Hal ini tidak sesuai dengan penelitian Padgett (2009), tentang konsumsi fast food pada generasi muda Cina yang menunjukkan bahwa variabel kontrol perilaku yang memiliki pengaruh paling kuat terhadap niat. Hal ini bisa dikarenakan bah

Penelitian Muna (2015), yang juga mengaplikasikan Theory of Planned Behavior menunjukkan adanya pengaruh sikap terhadap niat pelajar untuk berkendara sepeda motor di wilayah Surabaya Timur. Hal ini menunjukkan bahwa pada usia remaja sikap yang dimiliki mampu untuk mempengaruhi niatnya dalam berperilaku.

Pembentukan sikap yang baik bisa dari pengetahuannya tentang sayur dan buah yang baik juga. Menurut Notoatmodjo (2004) kurangnya pengetahuan tentang suatu bahan makanan akan menyebabkan sesorang salah memilih makanan sehingga akan menurunkan konsumsi makanan sehat dan akan berdampak pada masalah gizi lainnya.

Pada penelitian ini norma subyektif dan kontrol perilaku tidak menunjukkan pengaruh yang signifikan terhadap niat untuk makan sayur dan buah. Hal ini tidak sesuai dengan Theory of Planned Behavior (Azjen, 2005) bahwa norma subyektif dan kontrol perilaku merupakan variabel yang mempengaruhi niat. Norma subyektif yang dimiliki oleh seseorang dapat dipengaruhi oleh sejauh mana orang yang dianggap penting (Referent) dapat mendukung maupun melarang dalam memunculkan perilaku. Dapat disimpulkan bahwa pengaruh referent belum tentu bisa berpengaruh terhadap niat responden untuk makan sayur dan buah pada mahasiswa yang tinggal diasrama.

Norma subyektif berkaitan dengan keyakinan sesorang untuk mengikuti orang- 
orang yang dianggap penting seperti orang tua, orang dengan status sosial lebih tinggi, teman sebaya, teman dekat dan lain-lain. Hasil penelitian ini tidak sesuai dengan Gibney (2011), bahwa pengaruh khusus dari lingkungan sosial seperti tekanan sosial dari teman dan keluarga berdampak pada perilaku makan. Maltz (2004), juga menyatakan bahwa peranan tokoh penting atau tokoh otoritatif memberikan pengaruh yang sangat besar dalam pembentukan keyakinan yang akan menjadi landasan dalam berperilaku. Hal ini bisa dikarenakan mahasiswa asrama yang jauh dari keluarga mulai kehilangan panutan dari orang tua mereka dirumah dan mengakibatkan kurang peduli terhadap pola makannya. Tentu saja ini juga akan mempengaruhi niat mahasiswa dalam makan sayur dan buah.

Keluarga memiliki peranan yang sangat penting dalam pembentukan pola makan. Situasi dalam rumah merupakan hal yang dapat membangun sikap terhadap makanan dan penerimaan terhadap makanan tersebut. Pada umumnya ibu dipandang lebih berpengaruh daripada anggota keluarga lain karena peranan ibu sebagai pengatur rumah tangga dalam menyiapkan makanan seharihari. Banyak pesan yang disampaikan oleh ibu terkait konsumsi makanan merupakan bentuk dukungan sosial. Menurut Gottlieb dalam Laksono (2008), dukungan sosial dapat terdiri dari in formasi atau nasehat verbal maupun non verbal. Mahasiwa asrama yang jauh dari orang tua tentunya akan sulit mendapatkan dukungan sosial seperti ini. Hal ini dapat memungkinkan tidak adanya pengaruh antara norma subyektif dan niat untuk makan sayur dan buah pada mahasiswa yang tinggal di asrama. Jadi dapat disimpulkan bahwa dukungan sosial dari keluarga belum tentu mempengaruhi perilaku makan sayur dan buah.

Selain berasal dari orang tua, normative belief juga bisa berasal dari teman sebaya. Pengaruh teman sebaya adalah salah satu faktor yang menentukan pemilihan makanan oleh remaja. Remaja sangat menginginkan pengakuan dari teman sebayanya yang sering kali memberikan pengaruh besar terhadap pola makan termasuk dalam konsumsi sayur dan buah. Bagi seseorang kesesuaian sikap terhadap kelompok sebaya sangat penting untuk menjaga eksistensinya. Seringkali juga seorang remaja lebih ingin seperti teman-temannya sehingga kesesuaian sikap dengan keluarganya akan berkurang. Hal ini dapat mengakibatkan berubahnya pola makan remaja itu sendiri yang mungkin teman temannya tidak mendukung untuk makan sayur dan buah dan cenderung makan makanan yang kurang bergizi. Kebiasaan makan remaja mudah dipengaruhi oleh teman-temannya (Sutama, 2009)

Penelitian Seo et al (2011), menemukan bahwa konsumsi makanan cepat saji pada siswa sekolah menegah terkait erat dengan teman-temannya. Sebagian besar subyek penelitian mengungkapkan bahwa mereka makan makanan cepat saji ketika hari-hari khusus atau pada saat bertemu dengan teman-teman. Mahasiswa asrama yang jauh dari keluarga dan yang mungkin akan lebih sering bersama teman-temannya akan sangat mungkin untuk lebih sering makan makanan cepat saji dibandingkan untuk konsumsi sayur dan buah.

Kontrol perilaku merupakan persepsi mengenai sulit tidaknya melakukan perilaku tersebut. Hasil penelitian menunjukkan tidak adanya pengaruh kontrol perilaku terhadap niat. Hal ini tidak sama dengan penelitian Fauzia (2015), yang menyebutkan bahwa kontrol perilaku mampu mempengaruhi niat remaja untuk tidak merokok di Tuban. Hal ini menunjukkan bahwa kesulitan maupun kemudahan responden dalam makan sayur dan buah belum bisa untuk menjadi faktor yang mampu mempengaruhi niat untuk makan sayur dan buah pada mahasiswa asrama Universitas Airlangga.

Ada banyak faktor yang mempengaruhi pemilihan makanan oleh seseorang. Hartono (2004), mengatakan bahwa faktor yang mempengaruhi pemilihan makanan diantara adalah kesenangan dan ketidaksengajaan (food like and dislike) dan kebiasaan (food habit). Studi tentang pola konsumsi serat pada mahasiswa yang dilakukan Badrialaily (2004), menggambarkan bahwa banyak faktor yang menjadi kendala untuk makan sayur dan buah diantaranya adalah menu di warung yang tidak sesuai selera, ketersediaan, uang saku yang terbatas, dan preferensi terhadap sayuran tertentu. Faktor 
kendala tersebut belum tentu mempengaruhi niat mahasiswa untuk makan sayur dan buah, hal ini ditunjukkan dengan mayoritas responden yang memiliki kontol perilaku baik masih ada yang niatnya lemah untuk makan sayur dan buah.

Hambatan yang pertama adalah kesukaan seseorang dalam memilih makanan tertentu. Seseorang seringkali tidak suka terhadap makanan tertentu. Penelitian Farhatun (2012), tentang konsumsi serat pada mahasiswa menyebutkan bahwa penyajian jenis makanan bersumber serat tinggi seringkali kurang memikat selera makan dibandingkan dengan jenis makanan lainnya. Sayur dan buah merupakan salah satu makanan dengan sumber serat tinggi tersebut. Akibatnya mahasiswa seringkali tidak mau untuk makan makanan berserat tersebut. Hambatan kedua terkait dengan kontrol perilaku adalah ketersediaan sayur dan buah. Penelitian story et al (2002) dalam Waysima dkk (2011), menunjukkan bahwa faktor penting yang mempengaruhi perilaku makan remaja salah satunya adalah ketersediaan pangan. Mahasiswa yang tinggal di asrama kemunginan sulit untuk mendapat ketersedian sayur dan buah layaknya dirumah bisa menjadi penghambat untuk makan sayur dan buah sesuai kebutuhan. Hambatan ketiga terkait dengan uang saku untuk membeli makanan. Jika dilihat lagi mayoritas responden telah memiliki uang saku yang tergolong cukup untuk makan sayur dan buah. Hal ini tentunya yang juga bisa mempengaruhi kontrol perilakunya. Pada penelitian Zenk (2005), menunjukkan sesorang dengan penghasilan dan status ekonomi yang semakin meningkat akan lebih banyak dalam konsumsi sayur dan buah. Kenyataannya niat mahasiswa untuk makan sayur dan buah belum bisa ditentukan dari kontrol perilakunya.

\section{SIMPULAN}

Semua responden memiliki sikap dan norma subyektif yang baik dalam makan sayur dan buah tetapi masih ada responden dengan kontrol perilaku yang kurang baik. Hasil penelitian menunjukkan bahwa variabel sikap mempengaruhi niat untuk makan sayur dan buah mahasiswa. Sedangkan, Variabel Norma Subyektif dan Kontrol Perilaku tidak mempengaruhi niat untuk makan buah dan sayur pada mahasiswa asrama Universitas Airlangga. Sikap memberikan pengaruh yang posisitif terhadap niat makan sayur dan buah. Semakin baik sikap mampu menambah kuat niat sebesar 16 kalinya. Sedangkan responden dengan norma subyektif dan kontrol perilaku yang sudah baik belum tentu memiliki niat yang kuat untuk makan sayur dan buah. Mayoritas penghuni asrama mahasiswa Universitas Airlangga adalah perempuan dengan rentang usia 1821 tahun. Perempuan diketahui memiliki niat yang lebih besar daripada laki-laki untuk makan sayur dan buah. Mayoritas responden memiliki uang saku yang cukup untuk makan sayur dan buah. Uang saku memberikan pengaruh dalam hal memilih jenis makanan. Semakin besar uang saku maka semakin besar kesempatan untuk makan sayur dan buah.

\section{SARAN}

Bagi Asrama Mahasiswa Universitas Airlangga, dilihat dari sikap yang mampu mempengaruhi niat untuk makan sayur dan buah maka perlu adanya upaya pembentukan sikap yang baik melalui penguatan keyakinan responden tentang manfaat sayur dan buah. Hal ini bisa dilakukan dengan menambah informasi melalui media promosi kesehatan di lingkungan asrama. -Terkait kontrol perilaku responden yang menunjukkan masih adanya beberapa responden dengan kontol perilaku yang kurang baik bisa diatasi dengan memudahkan akses untuk makan sayur dan buah di lingkungan asrama, salah satunya dengan menyediakan menu sayuran dan buah-buahan yang beragam di kantin asrama.

\section{DAFTAR PUSTAKA}

Ajzen, I. 1985. From intentions to actions: A theory of planned behavior. In J. Kuhl \& J. Beckman (Eds.), Action-control: From cognition to behavior (pp. 11-39). Germany: Springer. 
Ajzen, I. 2005. Attitudes, Personality, and Behavior (2nd. Edition). England: Open University Press / McGraw- Hill.

Almatsier, S. 2004. Prinsip Dasar Ilmu Gizi. Gramedia Pustaka Utama, Jakarta.

Arisman. 2008. Buku Ajar Ilmu Gizi: Gizi dalam Daur Kehidupan. Jakarta: Penerbit Buku Kedokteran EGC

Badrialaily. 2004. Studi tentang Pola Konsumsi Serat pada Mahasiswa. Bogor: Departemen Gizi masyarakat dan Sumber Daya keluarga, Fakultas Pertanian IPB.

Bahria. 2009. Hubungan antara Pengetahuan Gizi, kesukaan dan Faktor Lain dengan Konsumsi Sayur dan Buah pada Remaja di 4 SMA di Jakarta tahun 2009. Skripsi. Depok. Fakultas Kesehatan Masyarakat UI.

Baker, Anna., Wardle , J. 2003. Sex Differences in Fruit and Vegetable Intake in Older Adults. Appetite, 40, 269-275

Brown, J.E. 2005. Nutrition Through the Life Cycle (edisi kedua). USA: Thomson Wadsworth.

Dauchet, Luc, et al. 2005. Fruit and Vegetable consumption and Risk of Stroke: A Metaanalysis of Cohort Studies. Neurology.

Departemen Kesehatan RI. 2014. Buku Studi Diet Total: Survei Konsumsi Makanan Individu Indonesia 2014. Badan Penelitian Dan Pengembangan Kesehatan Depkes RI.Jakarta Notoadmodjo, S., 2007. Promosi Kesehatan: Teori dan Perilaku. Jakarta: Rineka Cipta

Farhatun, S. 2012. Perilaku Konsumsi Serat Pada Mahasiswa Fakultas Kedokteran dan Ilmu Kesehatan Universitas Islam Negeri Jakarta Tahun 2012. Skripsi. UIN Jakarta.

Fauzia, WN. 2015.Aplikasi Theory of Planned behavior terhadap intensi remaja putra untuk berperilaku tidak merokok. Skripsi. Universitas Airlangga

Hartono, A. 2004. Terpai Gizi \& Diet Rumah Sakit, Ed 2. Jakarta: EGC.

He, F.J., C.A Nowson, M. Lucas, GA Mcgregor. 2007. Increased Consumption of Fruit and Vegetables is Related to Reduced Risk of Coronary Heart Disease: Meta-analysis of Cohort Studies. Journal of Human Hypertension.

Laksono, W.T. 2008. Hubungan Antara Dukungan Sosial dengan Intensi Berhenti
Merokok pada Mahasiswa. Skripsi. S1. Fakultas Psikologi Universitas Muhammadiyah Malang.

MacFarlane, Abbie, et al. 2007. Adolescent Home Food Environment and Socioeconomic Position. Asia Pac J Clin Nutr; 16(4): 748-756

Maltz, M. 2004. Psycho-cybernetics Mutakhir (The new Psycho-cybernetics). Interaksara. Jakarta

Muna,AN. 2015. Faktor yang Mempengaruhi Perilaku Berkendara Sepeda Motor Pada Pelajar SMP Berdasarkan Theory Of Planned Behavior. Skripsi. Universitas Airlangga

Padgett, BC., 2009. The Usefulness Of Theory of Planned behavior For Undersatnding U.S. Fast-Food Consumption Among Chinese Generation Y Consumers. Texas Tech University. USA

Poltekkes Depkes Jakarta I. 2010. Kesehatan Remaja: Problem dan Solusinya. Jakarta: Salemba Medika.

Rahmawati, D. 2000. Perilaku Makan Sayur Berdasarkan Sosiodemografi, Self Efficacy, Sikap, Niat, Preferensi, dan Ketersediaan Sayur Pada Murid Kelas VI SD Muhammadiyah 12. [Skripsi].

Rusdin. 2011. Pengaruh Sikap terhadap Perilaku, Norma Subyektif, dan Kontrol Perilaku yang Dirasakan terhadap Tindakan Memilih Penolong Persalinan di Puskesmas Rasana'e Timur Kota Bima. Skripsi. Surabaya: Universitas Airlangga. Sekarindah, T. 2008. Terapi Jus Sayur dan buah. Jakarta: Puspa Swara.

Seo, H.S et al. 2011. Factors Influencing Fast Food Consumption Behaviorsof MiddleSchool Students in Seoul: an Application of Theory of Planned Behaviors. Kore: The Korean Nutrition Society and the Korean Society of Community Nutrition.

Soekirman. 2000. Ilmu Gizi dan Aplikasinya untuk Keluarga dan Masyarakat. Jakarta : Direktorat Jenderal Pendidikan Tinggi, Departemen Pendidikan Nasional.

Sutama, A. et al. 2009. Buku Ajar Keperawatan pediatrik Wong, Ed 6, Vol 1. Jakarta: EGC

Thalib, S.B. 2010. Psikologi Pendidikan Berbasis Analisis Empiris Aplikatif . Jakarta: Kencana. 
Waysima, dkk. 2011. Persepsi dan Sikap Afektif Mempengaruhi Perilaku Ibu Menyediakan Makanan Ikan Laut dalam menu Keluarga. Bogor: Jurnal Ilmu Kearga dan Konsumen, Januari 2011, Vol.4, No.1. Institut Pertanian Bogor.

WHO. 2003. Fruits And Vegetables Intake In A Sample Of 11-Year-Old Children In 9 Europian Countries: The Pro
Children Cross- Sectional Survey. Ann Nutr Metab.

WHO. 2011. Noncommunicable disease country profiles 2011 WHO global report, Geneva. World Health Organization.

Wulansari, N.D. 2009. Konsumsi Serta Preferensi Buah dan Sayur Pada Remaja SMA dengan Status Sosial Ekonomi Yang Berbeda di Bogor. Skripsi. Institut Pertanian Bogor. 